\title{
Accounting
}

\section{Macroeconomic variables and portfolio investment in Bahrain using an ARDL bound testing approach}

\author{
Mohammad Salem Oudat $^{\mathrm{a}}$, Hafnida Hasan ${ }^{\mathrm{a}}$ and Ayman Abdalmajeed Alsmadi ${ }^{\text {** }}$
}

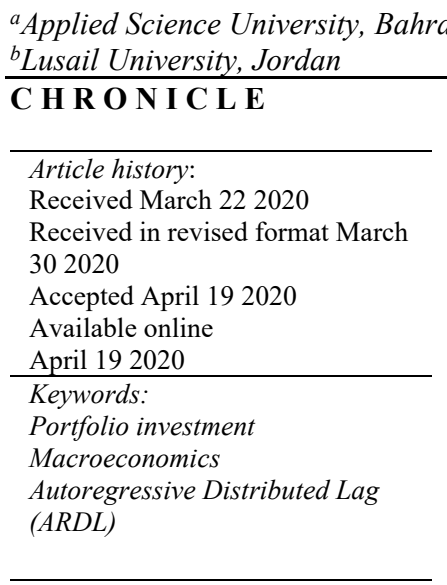

\section{A B S T R A C T}

The main aim for the current paper is to shed some light on some macroeconomic variables that affect the portfolio investment in one of the Middle East countries (Bahrain) for the period 1989-2018. Autoregressive Distributed Lag (ARDL) test was employed. The findings revealed that there was a long run relationship between portfolio and macroeconomic factors. The variable can cause portfolio investment only for consumer price index and gross domestic product in long run. Meanwhile, it found only consumer price index has statistically significant effect with portfolio investment in short-run.

\section{Introduction}

Economists and financial consultants always offer substantial advice in accordance with the famous proverb "don't put all your eggs in one basket", this means that if you prefer to have an efficient and profitable investment you should diversify your investment in different firms instead to rely into a single firm, that whether if there is an economic boom in the country and companies with high efficiency and profitability, these companies may suffer from the uncertainty and therefore the decline in value and may falter and fail, as a consequences you will lose your own wealth when you depend on single firm. Accordingly, to reduce the losses from single investment it is possible to formulate a portfolio investment. The main goal for portfolio investment is to maximize the return and minimize the risk. Harry Markowitz in his famous paper "Portfolio Selection, 1952" argued that the portfolio investment is a tool that contains of at least two different assets, and investor possessing an investment in portfolio empower him/ her to optimally utilise these assets. At the same time, using investment portfolios, investors could get the most out of the market value. In relation to this, the theory of modern portfolio is among the first financial theories that try to maximize anticipated return of portfolio for a certain amount of portfolio risk. Likewise, the theory attempts to minimize risk for certain estimated return level. This can be achieved by carefully selecting the proportions of various assets. By applying this method, decision can be made on what to invest: stocks, bonds or real estate. Further, investors employ quantitative data when forming the stock portfolio. This way, problems relating to optimization could be resolved. Aside from that, the modern

* Corresponding author

E-mail address: smadi370@yahoo.com (A.A. Alsamdi) 
portfolio theory incorporates the risk (variance) and return (mean), single- factor model (market model), multifactor model and capital asset pricing model (Markowitz, 1952, 1959). Moreover, investing in portfolio is required from the government side, to provide an encouragement factors to attract local and foreign investors to establish their investment, these factors include safety investment environment, stability financial sector, lower taxation system, and ease procedures to accesses. By providing these factors the investment will help to develop country economy. In Bahrain, the financial sector has played a vital role in demonstrating the country as the leading financial center in the region. In December 2006, the banking sector assets amounted to more than US \$ 180 billion. The growth of this sector in the Bahrain is due to the government following several factors such as the stable macroeconomic policies, open market economy, a credible regulatory framework and international standards, and a strong and well-qualified local labor force. All these factors have combined to strengthen Bahrain's position as a regional hub, as well as attracting many foreign banking and financial institutions to the country. Moreover, Bahrain has worked to create an appropriate investment environment and modernize the regulations, laws and regulations governing investment without hindering the process of the expansion of domestic investment and achieve its role in economic growth. The better the investment environment in the host country (domestic and foreign), the faster and stronger the impact of domestic and foreign direct investment on economic growth (The World Bank, 2018). Accordingly, In October 2017, the FinTech \& Innovation Unit was set up at the Central Bank of Bahrain to conduct market research on innovations taking place in the financial sector and to develop strategies for the effective utilization of emerging technology in order to be leading FinTech Hub in the Middle East As essential step in line with the implementation of the Bahrain Economic Vision 2030, which focuses on the economic development in the country and pay more attention to the financial sector and foreign investment. In line with Bahrain achievements, The World Bank recently recognizes Bahrain among the top 10 most improved economies in the world. (Bahrain Economic Development Board, 2019).

The present paper is conducting mainly to analyses the dynamic linkages between macroeconomic variables namely, Gross Domestic Product (GDP), Consumer Price Index (CPI), and Export Goods and Services (EGS), and Portfolio Investment (PI) in Bahrain for the period 1989 till 2018.

\section{Bahrain Economy during 1989 till 2018}

With its skilled and experienced human resources and a free economy, Bahrain is the ideal destination for starting a business, and the country is one of the least expensive to start a business compared to other countries in the region. The country has grown successfully over the past few years; economic free, and its clear vision to achieve growth and prosperity for all members of society. Bahrain's economy continued its upward trajectory in 2018 with a real GDP growth rate of $1.8 \%$. The non-oil, manufacturing and financial sectors grew by $2.5 \%$ in 2018 (The World Bank, 2018). Fig. 1 shows that the GDP has achieved an annual growth rate of $8.8 \%$ in Bahrain. It's obvious that Bahrain GDP has a continuous growth over the time. The country has reform different policies and strategies to improve its GDP and economic growth as well, the country pays more attention to financial sector as contains highly percentage to the GDP.

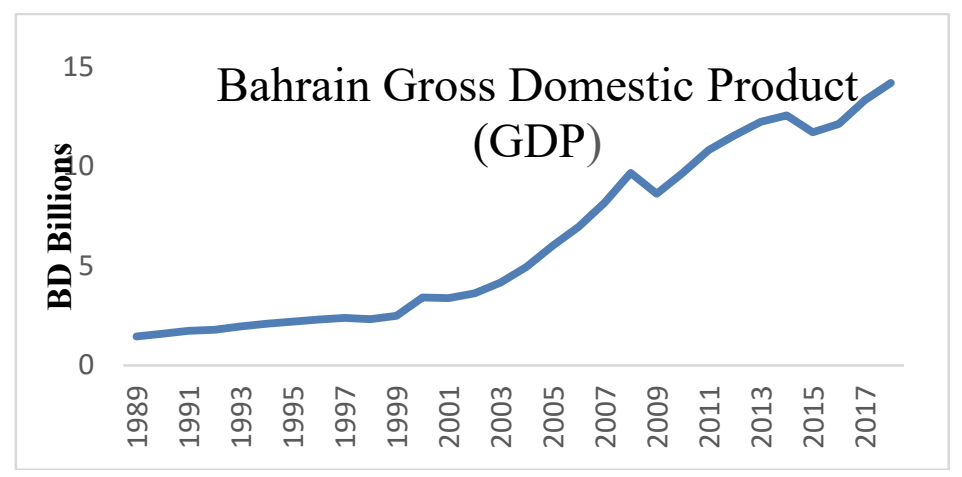

Sources: World Bank Development Indicators Database 2018, Available online at: https://data.worldbank.org/country/Bahrain

Fig. 1. Gross Domestic Product (GDP) for the 1989-2018 period

The country places different integrated packages of policies and legislations that regulate the investment to accelerate attracting foreign investors inside the country, which includes various tax and financial incentives for investment projects such as providing exemptions on equipment and capital goods and other incentives for the re-transfer of invested capital, as well as facilities in the field of basic services such as land, electricity, water, banking facilities, etc. and the possibility of establishing 
the project with full foreign ownership (Alsmadi \& Oudat, 2019). However, the foreign direct investment (FDI) has reached an annual growth rate of $2.55 \%$ for the period 1998 to 2018. The annual growth rate of consumer price index (CPI) in Bahrain for the period 1998-2018 recorded 1.40\% the growth was slightly increased during the period. oin the last year 2018 despite, the government imposed a tax by $5 \%$ at the beginning of 2018 but most basic goods and services which are considered components of the CPI, have not been taxed. Exports of goods and services denote all goods and services value that delivered to the other counties around the world. Those include the freight, merchandise, transport, travel, royalty's insurance, license personal fees, and other services, such as, information, construction, communication financial, business, and government services. They exclude compensation of employees and investment income (formerly called factor services) and transfer payments. The annual growth rate of export goods and services in Bahrain for the period 1989-2018 reached 0.087\%. Regarding to the portfolio investment is the form of a group (portfolio) of assets, counting transactions in equity, securities, such as common stock, and debt securities, such as banknotes, bonds, and debentures. The data of portfolio investment in Bahrain excluding liabilities constituting foreign authorities' reserves covers transactions in equity securities and debt securities. In 2017, portfolio investment for Bahrain was 3,214 million US dollars. Though Bahrain portfolio investment fluctuated substantially in recent years, it tended to decrease through 1998 - 2017 period ending at 3,214 million US dollars in 2017.

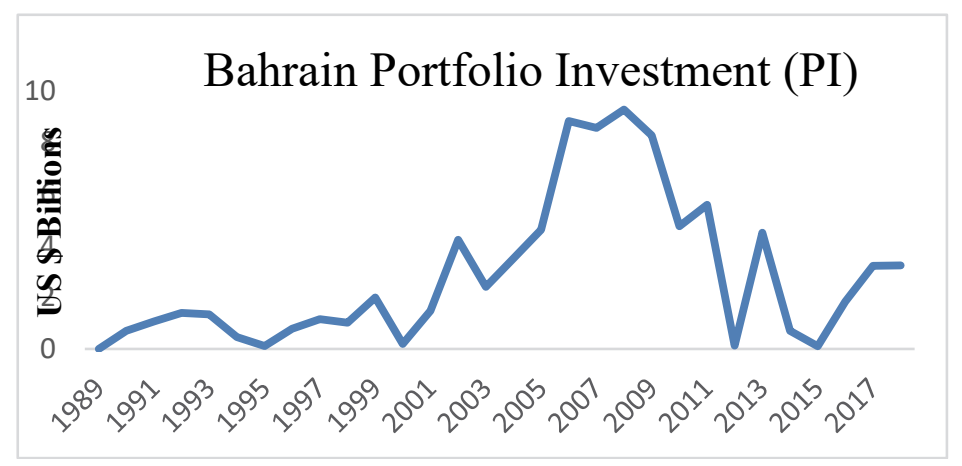

Sources: World Bank Development Indicators Database 2018, Available online at: https://data.worldbank.org/country/Bahrain

Fig. 2. Portfolio Investment in Bahrain (PI) for the 1989-2018 period

Fig. 2 reveals that the portfolio investment in Bahrain has achieved an annual growth rate of $8.4 \%$ for the 1989-2018 period. However, there is a fluctuation of the PI during the study period but for the last 2 years the performance of PI has been recovered and started to increased again due to different strategies and policies that the country implemented line with lunched the economic vision 2030 in the country and focused more on the financial sector.

\section{Literature review}

Portfolio investment and its determinants are broadly discussed in the existing literature. In this section, some empirical evidence from the developed and developing countries are presented. Agarwal (1997) evaluated the determinants of portfolio investment and its effect on the economy in six developing Asian countries. Regression results revealed that exchange rate, inflation rate, index of economic activity and the share of domestic capital market in the world stock market capitalization are four statistically significant determinants of portfolio investment. Rachdi and Saidi (2011) explored the impact of foreign direct investment and portfolio investment on economic growth on 100 developed and developing countries over the period 1990-2009, their empirical study reported the following findings; there is a statistically significant and positive relationship between foreign direct investment and economic growth when they used GMM, WG and GLS estimators related to pooled, developing and developed countries. Also, they found the coefficient of portfolio investment has negative and not statistically significant in developing countries. Nevertheless, this coefficient was positive and significant in developed economies when they employed the GMM estimator. In the same countries, when they include the random effect in the specification, the coefficient was positive relationship but not statistically significant. In all countries, the coefficient of portfolio investment was negative and significant.

Baghebo and Apere (2014) examined the impact of group of variables namely; portfolio investment, inflation rate, trade openness and market capitalization on the gross domestic product in Nigeria for the period of 1986 to 2011 using Johansen cointegration test the, their results fund that portfolio investment; trade openness has a positive long-run relationship with real gross domestic product in Nigeria. Winona and Nuzula (2016) also found in their article which conducted in Indonesia to examine the relationship between portfolio investment and economic growth for the period 2006-2014 that is significant effect. Singhania and Saini (2017) discussed the determinants of portfolio investment in developed and developing countries for a set of 19 countries for the period 2004-2013 employing fixed and random effects and panel generalized method of moments 
(GMM). Their findings showed that as a group of 19 countries, portfolio investments are significantly affected by interest rate differentials, freedom index, US stock market and host country stock market returns. Moreover, Chainman et al. (2018) evaluated the causal and dynamic linkage between macroeconomic variables and portfolio investment in West Africa using GMM techniques over the period of 1990-2016, their results showed that there were mixed results in portfolio equity and bond relationship with unemployment and balance of payment respectively. Portfolio equity has negative and statistically insignificant while portfolio bond has positive and insignificant. Also, Jabeen et al. (2018) explored the relationship between foreign direct investment and portfolio investment and real effective exchange rate using Johansen co-integration approach for the period 1985-2015. In addition, they employed granger causality and error correction techniques. The causality results showed there is no causal relation between foreign direct investment and foreign portfolio investment and real effective exchange rate. Moreover, the findings of the long run regression showed that there is a positive relationship between foreign direct investment and real effective exchange rate, while there is a negative relationship between portfolio investment and real effective exchange rate. However, the findings of short run regression showed that foreign direct investment has no impact real effective exchange rate while foreign portfolio investment has significant impact on real effective exchange rate. Moreover, Mugableh and Oudat (2018) explored the relationship between some macroeconomic variables (foreign direct investment, domestic market capitalization, money supply and government expenditure) and portfolio investment in Jordan for the period 1978-2016 employed ARDL approach and VECM model, the results showed that there was a positive relationship between the macroeconomic variables and portfolio investment, also the results of Granger causality revealed that there is a bidirectional causality between variables in both short-run and long-run. Recently, Ezeanyeji and Maureen (2019) measured the effect of portfolio investment on economic growth in Nigeria from 1986 to 2017, the economic growth presented by inflation, gross domestic product, rate, market capitalization and trade openness. The study employed Johansen cointegration technique and the error correction mechanism in the analysis. The results showed there is positive linkage between portfolio investment and economic growth in Nigeria. From the results of the previous researches, it can be concluded that even there is a number of studies emphasis a positive relationship between portfolio investment and economic growth measured by different methodologies but some studies found that there is a mixed result regarding to the portfolio and its determinants. The current study trying to add a new empirical results to the filed by examine the relationship between portfolio investment and three of a set macroeconomic variables; gross domestic product, consumer price index, export goods and services in one of emerging country.

\section{Theoretical Framework}

Osiegbu and Onuorah (2011), and Chi-Chi (2013), argued that financial system whether at country level or institutions level must have the capability to evaluate, monitor and manage business risks if it is carefully and productively invests capital flows, domestic or foreign. Its essential role of financial intermediation and credit allocation is one of main keys components of economic development. The portfolio investment can be a vital player in economic development, and offer more benefits and strengths for the country economy, but those strengths and benefits will be most effective when operating inside a healthy and strong financial system. In addition to the previous discussion about Modern Portfolio Theory (MPT), which is used to explain for the investors, how to select effective financial securities through diversification of their investments in order to maximize returns and minimize risk (Markowitz, 1952, 1959). There are different models and theories tried to explain the relationship between economic factors and return on securities such as, Capital Assets Pricing Model (CAPM) and Arbitrage Pricing theory (APT). However, to evaluate the stock price and expected return in portfolio, APT has come to contains undefined number of factors that cause securities returns to systematically deviate from their expected return. This theory allows for financial analytics to use various factors that might concluded in macroeconomic variables Ross (1976a, 1976b). Unlike CAPM which stated that the expected return of any financial asset is a linear function of its tendency to covary with the market portfolio market factor Sharpe (1964), Lintner (1965), and Mossin (1966). The relationship between GDP and portfolio investment (Edwards, 1999; Errunza, 2001; Duasa \& Kassim, 2009; Michael \& Baghebo, 2014; Meurer, 2016; Winona \& Nuzula, 2016; Mugableh, \& Oudat, 2018) found there is a relationship between some macroeconomic variables and portfolio investment.

\section{Methodology}

The analysis of this study uses annual time series data from 1989 to 2018 in Bahrain. The data are collected from World Bank indicator and International Monetary Fund (IMF). As stated by Pesaran et al. (2001) and Narayan (2005) that the sample size between 30 to 80 data set is accepted for time series data. Based on the objectives of the study, the following model was formed as follows:

$$
P I=f\left(G D P_{t}+E X P_{t}+C P I_{t}\right)
$$

where $P I$ is portfolio investment, $t$ is the year, GDP is gross domestic product, $C P I$ is consumer price index and $E X P$ is total export. 
The unit root test by Augmented Dickey Fuller is employed to conduct the stationary level of all variables at first different (Seddighi et al., 2000; Sahlan, 2010). So, the hypothesis for the unit root test is:

$H_{0}: \mu=0$ (exist of unit root or not stationary)

$H_{a}: \mu \neq 0$ (not exist of unit root or stationary)

According to hypothesis, if the t-statistic value greater than critical value, then will not be rejected the $H_{0}$. Meanwhile, if tstatistic less than critical value, then $H_{0}$ is rejected (no unit root). Then, the model (1) need to transform on the log form. The equation models as follows:

$$
L P I_{t}=\beta_{0}+\beta_{1} L G D P_{t}+\beta_{2} L E X P_{t}+\beta_{3} L C P I_{t}+L \varepsilon_{t}
$$

Next, the Autoregressive Distributed Lag (ARDL) is applied to examine the relationship between all variables in short run and long run. Using the assumption made by Narayan (2005) in Case III (Unrestricted intercepts and no trends) and imposes the restriction, $\vartheta_{x y}=0, \mu \neq 0$, thus the dependent variable and independent variable become:

$$
\begin{aligned}
& L P I_{t}=\beta_{0}+\beta_{1} L P I_{t-1}+\beta_{2} L G D P_{t-1}+\beta_{3} L E X P_{t-1}+\beta_{4} L C P I_{t-1} \\
& \quad+\sum_{i=1}^{p} \alpha_{1 i} \Delta L P I_{t-i}+\sum_{i=0}^{r} \alpha_{2 i} \Delta L G D P_{t-i}+\sum_{i=0}^{s} \alpha_{3 i} \Delta L E X P_{t-1}+\sum_{i=o}^{s} \alpha_{4 i} \Delta L C P I_{t-1}+\varepsilon_{t}
\end{aligned}
$$

where $\Delta$ is the first stage of differentiation, $\varepsilon_{t}$ is a white-noise disturbance terms and all variables are denoted on natural logarithm. Eq. (3) is considered as ARDL of order (p, q, r, s), which indicates that portfolio investments tend to be impacted and described by its past values besides the other explanatory variable. After regression Eq. (3), the Wald test (F-statistic) was calculated to differentiate the relationship between all variable in the long run. Thus, the hypothesis of this test is as follows:

$H_{0}: \beta_{1}=0$ and $\beta_{2}=\beta_{3}=\beta_{4}$ (no long run relationship)

$H_{a}: \beta_{1} \neq 0$ and $\beta_{2} \neq \beta_{3} \neq \beta_{4}$ (long run relationship)

Subsequently, Granger (1969) was conducted the causality test between two variables. In 1972, Sims has advanced this model as the causes model alternative (Asteriou \& Hall, 2007). The hypothesis of this causality model is as follows:

$$
\begin{aligned}
& H_{o}: \sum_{i=1}^{p} \beta_{i}=0 \text { or } X_{t} \text { not cause effect for } Y_{t} \\
& H_{a}: \sum_{i=1}^{p} \beta_{i}=0 \text { or } X_{t} \text { is cause effect for } Y_{t}
\end{aligned}
$$

According to the hypothesis, if the value of t-statistic is greater than the critical value then Ho will not be rejected. It indicates that no cause effect between both variable (X and $Y$ ). But, if the t-statistic is less than critical value it means there is a cause effect between variable $\mathrm{X}$ and variable $\mathrm{Y}$.

\section{Methodology Results}

The analysis begins with Augmented Dickey-Fuller (ADF) test for stationary to determine that there is long term relationship among the variables in the models. If variables found from Eq. (1) has the same level of stationary which is I(1), thus long run relationship or co-integration may exist between variables in the equations. It means that the regression result is not a spurious regression and it forms a similar wave in the long run. Table 1 demonstrates the statistics for unit root test in time series data. The results reveal that all variable is significant on first difference. For the first different, it found all variable stationary for no trend at $1 \%$ significant level except consumer price index (CPI) which significant at $5 \%$. Meanwhile, all the variables are stationary at $1 \%$ significance level on first different with trend. Therefore, the data meet the requirement to apply the Autoregressive Distributed Lags (ARDL) bounds approach for determining the long-run relationships among the variable which suggested by Pesaran et al. (2001).

Table 1

Augmented Dickey Fuller (ADF) test for a unit root test

Variable Level $\quad$ First Difference




\begin{tabular}{lllll}
\hline & No trend & With trend & No trend & With Trend \\
\hline LPI & $-6.2128^{* * *}$ & $-5.9373 * * *$ & $-6.1461 * * *$ & $-5.9635^{* * *}$ \\
LCPI & 1.0561 & -1.6341 & $-1.9596^{* *}$ & $-3.7146 * * *$ \\
LGDP & -0.6399 & -1.3007 & $-4.7706^{* * *}$ & $-4.7025^{* * *}$ \\
LEXP & -0.4519 & -3.1695 & $-4.8219 * * *$ & $-4.7174 * * *$ \\
\hline
\end{tabular}

Note: the number of lag was selected based on Akaike Information Criterion (AIC). ${ }^{*}, * * * *$ denote $10 \%, 5 \%$ and $1 \%$, respectively.

\section{Co-integration tests}

The ARDL approach begins with to test the relationship between independent and dependent variable in long run. It involves the comparison of the F statistics against the critical values, which created for sample sizes by Narayan (2005). Based on the result in Table 2 we have found that the $\mathrm{F}$ statistic value was larger than the upper critical value at $5 \%$ significant level for Bahrain. This condition presences of valid long run relationships among portfolio investment, gross domestic product, consumer price index and export.

Table 2

Bound testing for the existence of long-run relationship

\begin{tabular}{lcc}
\hline Model & \multicolumn{2}{c}{ F statistic } \\
\hline Model 1 & $5.1409 * *$ \\
\hline & Lower bound & Critical value $^{\#}$ \\
$1 \%$ significance level & 5.333 & Upper bound \\
$5 \%$ significance level & 3.710 & 7.063 \\
$10 \%$ significance level & 3.008 & 5.018 \\
\hline
\end{tabular}

Note: \# is the critical values are obtained from Narayan (2005). ${ }^{*}, *$ and ${ }^{* * *}$ denote significant at $10 \%, 5 \%$ and $1 \%$ significance levels.

To ascertain the goodness of the ARDL model, it is important to check the robustness of model by implementing diagnostic test and the stability test. It involves, Breush-Godfrey serial correlation LM test, Jarque-Bera normality test, ARCH test and Ramsey RESET test. Table 3 demonstrates that there was no evidence of autocorrelation, homoscedastic and that models pass the normality test, which proven that the error is distributed normally. All test given the value of probability of the t-test is all above than $10 \%$ significant value.

Table 3

Diagnostic test for ARDL model

\begin{tabular}{ll}
\hline Test & Value \\
\hline LM test $^{\mathrm{a}}$ & $0.387(0.4801)$ \\
Jarque-Bera $^{\mathrm{b}}$ & $0.2882(0.8657)$ \\
Ramsey RESET test $^{\mathrm{c}}$ & $0.0029(0.9573)$ \\
ARCH test $^{\mathrm{d}}$ & $0.7034(0.3900)$ \\
\hline
\end{tabular}

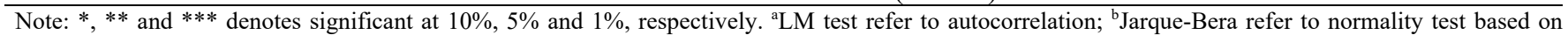
skewness and kurtosis residual; ${ }^{\mathrm{C}}$ Ramsey RESET test using the square of the fitted values; ${ }^{\mathrm{d}} \mathrm{ARCH}$ based on the regression of squared residuals on squared fitted values.

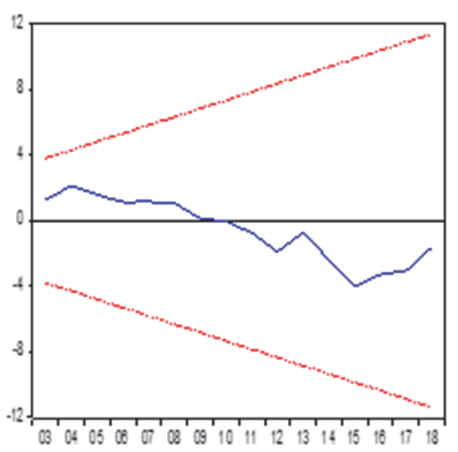

Plot of Cumulative sum of Recursive Residuals

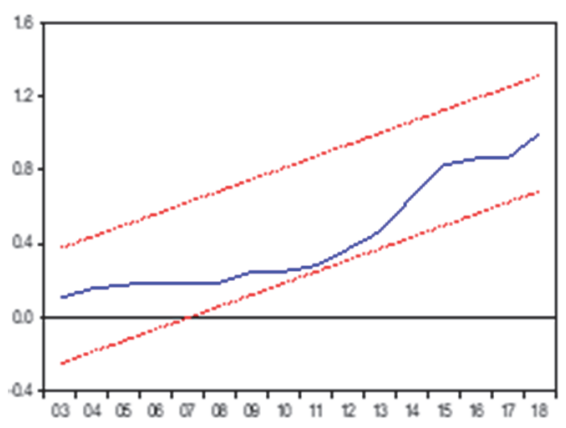

Plot of Cumulative Sum of Squares of Recursive Residuals

Fig. 1. CUSUM and CUSUMQ

Finally, the cumulative sum of recursive residuals (CUSUM) and cumulative sum of squares of recursive residual CUSUMQ) are utilized to analyze the stability of coefficients in the long run incorporate with the dynamic short run model. Fig. 1 
demonstrates the statistics result of CUSUM and CUSUMQ. It is clear that both plots in CUSUM and CUSUMQ were within the boundaries. Therefore, it can be concluded that there is stability of the long run coefficient of portfolio investment, gross domestic product, export and consumer price index.

\section{Long-Run and Short Run Results}

The first stage of ARDL analysis with the existence of the coefficients in Eq. (3) in the long run is estimated and the findings are mentioned in Table 4. The result found that the variable of consumer index has a significant effect on portfolio investment; a $1 \%$ increase in these variable leads to decrease in portfolio at 10.75 . The coefficient of gross domestic product in Bahrain is statistically significant. If we consider the effect of gross domestic product on portfolio investment, a $1 \%$ increase in gross domestic product leads to 4.63 increase in portfolio investment. Meanwhile, the export has no significant effects on portfolio investment.

\section{Table 4}

The Estimated Long-run Coefficient results

\begin{tabular}{ll}
\hline Variables & Results \\
\hline C & $20.412^{* *}$ \\
LCPI & $-10.754 * *$ \\
LGDP & $4.627 * *$ \\
LEXP & -2.366 \\
\hline Note: $* * *$ and $* * *$ denote significant at $10 \%, 5 \%$ and $1 \%$ significance levels.
\end{tabular}

Next, Table 5 displays the results of the error correction test and finds a long-run error correction terms (ECT). The ECT values is found to have the expected negative sign and statistically significant for Eq. (2). The short-run relationship exists between consumer price index and portfolio investment at $10 \%$ significant level. A $1 \%$ increase in consumer price index can cause a $11.54 \%$ decrease in portfolio investment in short run. Meanwhile, the other variables such as gross domestic product and export has no significant effect on portfolio investment.

\section{Table 5}

The Estimated Short-run Error Correction term (ECT-ARDL) results

\begin{tabular}{ll}
\hline Variables & Results \\
\hline C & $21.894^{* *}$ \\
LCPI & $-11.535^{*}$ \\
LGDP & 5.028 \\
LEXP & -2.538 \\
ECT $\mathrm{t}-1$ & $-1.072 * * *$ \\
\hline
\end{tabular}

Note: $* * *$ and $* * *$ denote significant at $10 \%, 5 \%$ and $1 \%$ significance levels.

\section{Conclusion}

Nowadays, portfolio investment is one of the important indicators that affect the stability of financial system. Thus, the objective of this study was to shed some light on some macroeconomic variables that affect the portfolio investment in Bahrain for the period 1989-2018. The result of unit root test has found that all variables were stationary at first difference with trend. Then, we could proceed to co-integration test. ARDL result found that there was long run relationship between all variables. The estimated coefficient for long run has shown that gross domestic product and consumer price index had significant effect on portfolio investment. Meanwhile, only consumer price index has statistically significant in short run with portfolio investment.

\section{References}

Agarwal, R., N., (1997), Foreign Portfolio Investment in Some Developing Countries: A Study of Determinants and Macroeconomic Impact. Indian Economic Review, 32(2), 217-229.

Alsmadi, A., A., \& Oudat, M., S., (2019), The Effect of Foreign Direct Investment on Financial Development: Empirical Evidence from Bahrain, Ekonomski Pregled, 70(1), 22-40.

Asteriou, D. \& Hall, S. G. (2007). Applied Econometrics: A Modern Approach Using Eviews and Microfits. New York: Palgrave Macmillan.

Baghebo, M., \& Apere, T. (2014). Foreign portfolio investment and economic growth in Nigeria (1986-2011). International Journal of Business and Social Science, 5(11), 108-115. 
Bahrain Economic Development Board, (2019), (October 25, 2019). Available online at: https://bahrainedb.com/. Access $05^{\text {th }}$ /November $/ 2019$.

Chi-Chi, O., A., (2013), Impact of Macroeconomic Indicators on the Performance of Foreign Portfolio Investment in Nigeria. European Journal of Business and Management, 5(2), 81-901.

Edwards, S. (1999). How effective are capital controls? Journal of Economic Perspectives, 13(4), 65-84.

Errunza, V. (2001). Foreign portfolio equity investments, financial liberalization, and economic development. Review of International Economics, 9(4), 703-726.

Ezeanyeji, C. I., \& Maureen, I., (2019), Foreign Portfolio Investment on Economic Growth of Nigeria: An Impact Analysis. International Journal of Academic Management Science Research, 3(3), 24-36.

Chainman, O., F., Chinaemerem, O., P., \& Kingsley, O. (2018). Does foreign portfolio investment drives macroeconomic variables of West Africa? Disaggregated approach. Journal of Economics, Management and Trade, 21(7), 1-10.

Jabeen, M., Naz, F., \& Ihsan, H., (2017), Capital inflows and Real Effective Exchange Rate: Empirical Evidence from Pakistan, Conference Paper · October 2017, https://www.researchgate.net/publication/325905691.

Lintner, J., (1965). The valuation of risk assets and the selection of risky investments in stock portfolios and capital budgets. Review of Economics and Statistics, 47, 13-37.

Markowitz, H. (1952). Portfolio Selection. Journal of Finance, 7, 77-91.

Markowitz, H., (1959). Portfolio Selection: Efficient Diversification of Investment. New York: John Wiley and Sons.

Meurer, R. (2016). Portfolio investment flows, GDP, and investment in brazil. International Journal of Economics and Finance, $8(12), 1-9$.

Mossin, J. (1966). Equilibrium in a Capital Asset Market, Econometrica, 34, 768-783.

Mugableh, M., I., \& Oudat, M., S. (2018). Modelling the determinants of foreign portfolio investments: A bounds testing and causality analysis for Jordan. Academy of Accounting and Financial Studies Journal, 22(4).

Narayan, P. K., (2005). The saving and investment nexus for China: Evidence from cointegration tests. Applied Economics, 37.

Onuorah, A. C., \& Akujuobi, L. E. (2013). Impact of macroeconomic indicators on the performance of foreign portfolio investment in Nigeria. European Journal of Business and Management, 5(2), 81-90.

Pesaran, M. H., Shin, Y., \& Smith, R. J., (2001). Bounds testing approach to the analysis of level relationships. Journal of Applied Econometrics, 16, 289-326.

Rachdi, H., \& Saidi, H., (2011), The Impact of Foreign Direct Investment and Portfolio Investment on Economic Growth in Developing and Developed Economies, Interdisciplinary Journal of Research in Business, 1(6), 1.

Sahlan, R., (2010). Ekonometrik: Teori dan Aplikasi. Malaysia: Cengage Learning.

Seddighi, H. R., Lawler, K. A. \& Katos, A. V., (2000). Econometrics: A Practical Approach. New York: Routledge.

Singhania, M., \& Saini, N., (2017), Determinants of FPI in Developed and Developing Countries, Global Business Review, 19(1), 187-213.

Winona, A., A., W., S \& Nuzula, F., N. (2016), The Relationship Between Foreign Portfolio Investment and Foreign Direct Investment on Economic Growth (Study At Indonesia Stock Exchange And Bank Of Indonesia Period 2006-2014), Jurnal Administrasi Bisnis, 31(2), 44-49.

World Development Indicators Database (2018). Retrieved from http://databank.worldbank.org/ data/reports.aspx?source=world-development-indicators

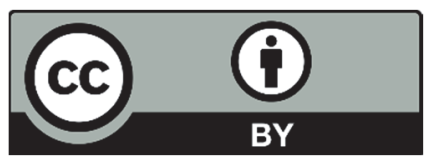

(C) 2020 by the authors; licensee Growing Science, Canada. This is an open access article distributed under the terms and conditions of the Creative Commons Attribution (CC-BY) license (http://creativecommons.org/licenses/by/4.0/). 